\title{
Introduction
}

There is a saying in the Balkans that behind every hero stands a traitor. The difficulty, as often as not, is to determine which is which. Again and again, there is something heroic about the traitor and something treacherous about the hero. (Fitzroy MacLean, The Heretic)

I 1991, THE WORLD watched in amazement as the Socialist Federative Republic of Yugoslavia (SFRY) began what was seemingly a fratricidal civil war. Formerly peaceful republics, joined for almost five decades under the banner of 'Brotherhood and Unity', would soon end their coexistence when the Yugoslav People's Army (JNA) rolled into Slovenia to prevent Slovenian independence by force. In Croatia, Serbian irregulars instigated violent clashes with Croatian paramilitary forces, followed once more by the intervention of the JNA. As the fighting spread from Eastern Slavonia to the Krajina, and then south-east to Bosnia-Hercegovina, it was clear that Europe was witnessing its first major military conflict since the Second World War, and few understood what was going on.

While several constituent nations, such as the Macedonians, Montenegrins, and Slovenians, played a peripheral role in the conflict, the principal actors were to be the Kosovar Albanians, the Bosnian Moslems, the Serbs, and the Croats. The wars that followed the collapse of Yugoslavia would be dominated by an intense Serbian-Croatian rivalry. As extremely bloody wars were being fought on the ground, a war of words took place through magazines, journals, newspapers, and books, as well as on television, the radio, and the internet. All modern means of communication were actively subordinated to the goals of ethnic nationalist leaders in Serbia and Croatia, seeking to promote revised images of their respective histories.

This book explores the rather strange predicament Western observers encountered when trying to understand the collapse of Yugoslavia. Seven distinct national groups, each with their own religious traditions, colonial history, and cultural trappings, had lived in relative peace since 1945 . Now 
four of these sought to advance the same claim - that they were victims of the first genocide on European soil since the Second World War. Serbs, Kosovar Albanians, Croats, and Bosnian Moslems each claimed to be defending themselves from annihilation, arguing that one or more dangerous enemies were trying to destroy their nation, according to an age-old blueprint for hatred and treachery. Images of Serbian, Croatian, Bosnian Moslem, and Kosovar Albanian genocides and 'holocausts' frequently appeared in the popular media, and the reader, listener, or internet surfer was berated with a continuous stream of material, all seemingly arguing the same thing: "we are the victims first and foremost - our war is legitimate because we are fighting against annihilation'.

The French Slavicist Paul Garde, at a recent gathering in Paris to unveil the second edition of his 1992 classic Vie et mort de la Yougoslavie, noted that at the beginning of the war he was severely hampered by a lack of information, not only in terms of factual reporting, but more importantly in terms of viewpoints, as to how each side was justifying its role in the conflict. Nine years later he had exactly the opposite reaction - there was a superfluity of information, and contemporary books on Yugoslavia adorned two entire walls in his large study. In 1991, there was practically nothing to be found on the conflict; but within two years, a war of journals, books, pamphlets, newspapers, and internet sites had begun. Croatian journalist Slavenka Drakulić described this early period in Balkan Express: 'Long before the real war, we had a media war, Serbian and Croatian journalists attacking the political leaders from the opposite republic as well as each other as if in some kind of dress rehearsal. So I could see a spiral of hatred descending on us, but until the first bloodshed it seemed to operate on the level of a power struggle that had nothing to do with the common people.' 1

The former American Ambassador to Yugoslavia, Warren Zimmermann, added this more prescient comment during the escalation of hostilities in 1992: 'What we witnessed was violence-provoking nationalism from the top down ... Many people in the Balkans may be weak or even bigoted, but in Yugoslavia, it is their leaders who have been criminal.' Historian Noel Malcolm described the climate in Serbia before the war as comparable to 'all of television in the USA [being] taken over by the Ku Klux Klan'.2 And what was true of Serbia was sadly often true of Croatia as well.

This book will address two particular problems: the manipulation of victim imagery, and the powerful war of words that accompanied and often preceded military violence. Of central importance is understanding how and why each side so assiduously chose to portray itself as a victim of genocide, not just in the present, but also in the past. Anyone who followed the conflict from 1991 onwards would have been struck by the constant emphasis on historical victimisation and suffering. This situation paradoxically gave rise to the 
view that the wars in Yugoslavia were the result of 'ancient ethnic hatreds' between traditionally hostile ethnic groups. Such propaganda would confuse rather than clarify. ${ }^{3}$ While it is important to explore the nature of such imagery, it is also important to understand the philosophical and theological underpinnings of a victim-centred strategy in nationalism, while systematically unravelling and comparing Serbian and Croatian propaganda. This involves charting how different periods of history have been revised to make a nation's history one of constant danger, defeat, and martyrdom.

There have been several attempts to understand the nature of Serbian propaganda. Some examples of Serbian propaganda analysis include Branimir Anzulović's Heavenly Serbia, Anto Knezević's Analysis of Serbian Propaganda, and Philip Cohen's Serbia's Secret War. Of these, only Anzulović's analysis does not seem to advance an overtly pro-Croatian viewpoint. Whatever the motivations of these writers, their greatest sin by far has been to study Serbian writing by itself, without adequate reference to what Croats, Kosovar Albanians, or Bosnian Moslems were also arguing at the same time. This has only decontextualised Serbian nationalism, removing it from the environment in which it was written and distributed. Since many Serbian writers were actively debating facts about historical dates, numbers, and key historical personalities with the other parties to these conflicts, studying only one side ignored the motivations and provocations of the Serbs.

Without a clear view of Serbian and Croatian arguments, half the debate is missing. Clearly, a comparative study of Serbian and Croatian propaganda is long overdue. While it is obvious that the Serbs were the main aggressors in Bosnia, Croatia, and Kosovo, there is no doubt that Croats, Kosovar Albanians, and Bosnian Moslems were not simply innocent bystanders, waiting to be 'ethnically cleansed'. There were many examples of these other three groups either instigating violence, or responding to it with force of their own.

To many, it might seem obvious why Serbs and Croats would have wished to portray their histories as long periods of suffering and decline, why playing the victim should now, more than ever, seem like a good idea. Since the introduction of the United Nations Conventions on Genocide and Human Rights in 1948, many people have felt a greater sense of responsibility for human rights abuses around the world. Rather than adopting a policy of non-interference in the internal affairs of other countries, we have become more concerned about what goes on behind closed doors, and more interventionist than ever before. Many feel that the existence of UN conventions gives us the right and the duty to 'care' for the treatment of other people living under despotic regimes. This is a relatively new phenomenon. Geoffrey Robertson has argued that before the Second World War: 'It dawned on no political leader, even after the carnage of the First World War, that international institutions might tell 
states how to treat their nationals.' 'Human rights', he suggests, mattered little until 'Hitler made them irrelevant.'

Since 1945, many Western academics have assured themselves that the heyday of Nietzschean nihilism is past. Most no longer believe that the weak are extinguished by history, nor do they believe that the 'will to power' is all one needs to control the world. Rather, we tend to sympathise with the victims rather than the aggressors. The human rights sociology favoured by journalists and academics such as Michael Ignatieff demonstrates that the rights of others, or as he terms it 'the needs of strangers' override our more common impulses to stick to our own business and keep our noses out of trouble. ${ }^{5}$ Elazar Barkan recently identified a 'victim culture' as becoming increasingly important in international affairs, as evidenced by the plethora of restitution cases that emerged during the 1980s and 1990s. As he explains in The Guilt of Nations:

No longer does the brute and immediate existential need for security form the sole legitimate justification or motive in formulating foreign policy. Instead, opposition to genocide, support for human rights, and the fear of being implicated in crimes against humanity (even by inaction) have become practical, not merely lofty, ideals. These ideals increasingly shape political decisions and the international scene. ${ }^{6}$

In Yugoslavia, an obvious solution for nations struggling to free themselves from decades of Communist rule was to portray themselves as victims to appeal to a heightened sense of global responsibility and morality. While Serbs and Croats both shared a historic belief in their own victimisation as nations, I will argue that this sense of victimisation was exacerbated during the Tudjman and Milošević eras, and became a central pillar of national identity. The NATO-led bombing of Bosnian Serb positions in 1995, and rump-Yugoslavia in 1999, demonstrated that violence against minorities (at least in Europe) would not be tolerated indefinitely. Once Roy Gutman's lead article in Newsday in 1992 - 'The Death Camps of Bosnia' - established the Moslems as victims of seemingly Nazi-esque atrocities, America seriously began to get involved. ${ }^{7}$ Sadly, such intervention, even if too late to prevent the horrors of Manjaća, Omarska, and Trnopolje, was not to be found at all in Rwanda, East Timor, or Chechnya.

The rise of Non-Governmental Organisations (NGOs), with tremendous resources and media power, should also alert our attention to the very real benefits to be gained by portraying oneself as the victim of aggression. Human Rights NGOs now dominate the international arena; by 1994, some 67 per cent of the European Union's relief aid was channelled through such organisations. According to the International Red Cross, NGOs collectively disburse more money than the World Bank. One quarter of Oxfam's $£ 98$ million budget comes from governmental sources, while in 2000 World Vision US gained 
$\$ 55$ million in aid from the American government. ${ }^{8}$ These groups have a direct line to governments around the world, contributing to agenda setting. They help to define who is a victim and how victimised they are. They also wield considerable power in determining the identity of aggressors, even if, as in the case of Rwanda, there is little international will to carry out their recommendations.

Generally, we live in a world where victims are now the subject of pity and financial assistance, not scorn. While these are compelling reasons that explain the practicalities of portraying oneself as a victim, this does not explain why we as outside observers have become more receptive to claims of victimisation. Neither Serbs nor Croats were seeking to curry the favour of NGOs, nor did they invoke international conventions against each other during the conflict itself. ${ }^{9}$ Certainly, both sides were seeking international recognition for the new state of affairs in their respective republics. The breakdown of federal authority and legitimacy in Communist Yugoslavia after Josip Broz Tito's death in 1980 changed the nature of the country considerably.

The republics, rather than the federal centre, became the new loci of power, as republic-based elites began building networks of power and influence. Tito's Communism was never able to guarantee the withering away of the state. While he promised that the borders of Yugoslavia's individual republics were nothing more than 'lines on a marble column', it was clear that borders continued to play a pivotal role in Yugoslav politics. After his death in 1980 , every aspect of his system was open to dispute, including the administrative divisions of the country, which in some cases were also national.

It is important to understand not only why Serbs and Croats sought to reconstruct their histories as periods of suffering and persecution, but also why Western policy-makers appeared receptive. Chapters 1 and 2 explore how and why victim-centred propaganda has become important in the modern world. Chapter 1 examines how early national entities developed myths, in order to advance a unique view of their place in world history. For the ancient Hebrew nation, a cyclical form of teleology, composed of a Golden Age, a Fall, and a Redemption, constituted what Northrop Frye and others have termed a 'covenantal cycle'. Covenants imply faith in an omnipresent, omnipotent god, able to guide the nation in times of distress and hardship. In return for obedience and faith, the Hebrew god assured his people of their divine election and their 'chosenness' - making them a more spiritual, more special people than any other. Ideas of Covenant, chosenness, Golden Age, Fall, and Redemption have formed the core of several modern nationalisms.

Another important aspect of cyclical teleology has been the constant battle between good and evil throughout history - the 'chosen' nation versus its many enemies. The links between such mythology and Serbian and Croatian nationalism will become obvious. Both subscribed to a cyclical view 
of history; both groups saw themselves as 'chosen' and unique, while at the same time, they portrayed their own histories as a series of battles against powerful enemies. Both groups consistently held that by proving their own Falls throughout history, they could legitimate the struggles necessary for Redemption.

In Chapter 2, the twentieth-century application of these early JudaeoChrisitan concepts will be understood with reference to the Jewish Zionist movement. There was much in Serbian and Croatian nationalism that relied on the Zionist contribution to the history of ideas. For nineteenth-century Zionists, the presence of anti-Semitism confirmed for some that the only way the Jewish people would be free of persecution was through their own Redemption in a territorially bounded nation-state. Zionists modernised cyclical teleology and used it to create their own state, free from the horrors of centuries of discriminatory legislation, pogrom, and massacre. Perhaps the most important aspect of Zionism, however, was something over which they had little control. The Holocaust, which occurred between 1941 and 1945, saw almost 6 million Jews systematically killed by the German Nazi regime arguably the greatest Fall in the history of Judaism. Some viewed the creation of the State of Israel in 1948 as the greatest recompense and Redemption since the restoration of the Kingdom some 2,000 years before. Thus, the greatest Fall and Redemption of the twentieth century followed one after the other within a three-year period.

An important concept throughout this work will be the idea of performing, or acting out a genocide. On the basis of the legacy of Jewish suffering and the perception (or misperception) that the Holocaust was instrumentalised by Zionist leaders to achieve the State of Israel, historians from marginalised nations, including the Romani, the Armenians, and the Ukrainians, have compared their own historical persecution to that of the Jews. Such historical revisionism has formed the basis of a 'comparative genocide debate', which employs the images and symbols of the Holocaust as a template. This debate has pitted a number of Jewish historians (who argue that the Holocaust is a unique and unprecedented event in modern history) against another group of historians, who claim that their own group's experience of suffering is equal to or in some respects worse than that of the Jews. For many national groups, articulating myths of persecution and victimisation has become an essential part of reconstructing histories and legitimating state-building projects. As I will demonstrate from Chapters 3 to 8 , Serbs and Croats entered into this timely and controversial debate. Both groups used claims of victimisation and persecution to legitimate their own state-building or state-expanding projects, with often violent consequences.

Both the Judaeo-Christian covenantal culture and the instrumentalisation of Holocaust imagery have been of central importance in structuring 
Serbian and Croatian representations of the past and present. History was reinvented in the 1980s and 1990s, in order to paint each nation as a longsuffering victim of ancient, predatory enemies, bent on their destruction. The following chapters will discuss how Serbs and Croats used such imagery to their advantage. For both groups, portraying history as a series of neverending 'ancient ethnic antagonisms' or 'centuries of hatred' performed an important function. Events in the 1980s and 1990s were presented as only an extension of past conflicts. By proving that the Other had been an aggressor throughout history, one could prove that history was repeating itself, that the nation was simply defending itself against yet another attempt at annihilation.

As Yugoslavia slowly collapsed, gone was any ambiguity or inner reflection about how one's nation might have committed historic atrocities. A Manichaean morality pervaded both sides, in which the other was unequivocally evil, and the self could do no wrong. Any periods of friendly association or harmonious political projects (such as Illyrianism or Yugoslavism) were excised from a history that became more and more decontextualised. More 'authentic' national enemies, such as the Ottomans, the Bulgarians, the Austro-Hungarians, and the Italians, were quietly brushed aside as mere backdrops to the more important contest between Serb and Croat. Even Nazi Germany emerged more as a facilitator of Serb and Croat evil, than as the instigator of crimes in the Balkans.

Chapter 3 begins with the rise of nationalism in Serbia, from the death of Josip Broz Tito in 1980 to Slobodan Milošević's historic speech in 1987 to the Kosovo Serbs, pledging to defend their national rights in Kosovo, no matter what the cost. Milošević's genius was to identify the Kierkegaardian 'right moment' in Serbian politics, when he was able to transform himself from a Belgrade banker and communist official into a nationalist phenomenon. Milošević, however forceful a speaker, was never much more than an opportunist. Nevertheless, his own lack of fundamentalism would be mitigated by the presence of dozens of nationalist believers, from author-politicians Dobrica Ćosić and Vuk Drasković, to paramilitary warlords such as Željko Ražnatović Arkan and Vojislav Šešelj.

The invention of 'Serbophobia', often likened to anti-Semitism, was a curious facet of the conflict. Serbs would continually compare themselves to the Jews as fellow victims in world history. This invariably involved a tragedising of history, from the 1389 Battle of Kosovo to the 1974 Yugoslav Constitution - every aspect of Serbian history was seen to be another example of persecution and victimisation at the hands of external negative forces. The Kosovar Albanians, as the first group within part-Tito Yugoslavia to experience a national awakening (in 1981), were the first targets of Serbian nationalism. Kosovo would be important as a template or pattern for the more 
important propaganda war against the Croats - Serbia's most important competitor during the break-up of Yugoslavia. This chapter will concentrate on the early threats of Croatian nationalism - its strong links to a supposedly xenophobic and expansionist Roman Catholic Church, its genocidal ambitions against Serbia during the nineteenth century, and its hatred of diversity and compromise in the first Yugoslavia.

For Croats, the issue of persecution would be of equal importance. Chapter 4 begins with the rise of Franjo Tudjman and his Croatian Democratic Alliance (HDZ). Tudjman was a true believer in the nationalist cause, and in Croatia there was a thorough process of centralising power and propaganda within the state. Croatian propagandists focused most of their attacks on Serbia, which was in the process of invading and occupying one-quarter of their newly independent country. Croatian reappraisals of history often involved the conjuring up of a 'Greater Serbia' - an evil, expansionary, annihilatory other, seeking first to invade, then to enslave, and then to exterminate the Croatian people. From the time of the Great Schism between Catholic and Orthodox worlds, Croats were supposedly confronted with a Serbian desire to destroy small and peaceful nations. Other key historical periods include the nineteenth century, when the ideals of 'Greater Serbia' were supposedly put into practice, through to the First Yugoslavia after the First World War, when Serbs and Croats entered, along with the Slovenes, into political association for the first time in their history.

Other important myths include the Antemurale Christianitatis, the belief that Croatia represented the easternmost outpost of European civilisation. Across the divide were the Serbs, often presented as being on a lower level of civilisation, with an 'Asiatic' mentality, and distinct racial and psychological features, as well as different linguistic and cultural forms of identity. Such forms of differentiation would buttress Croatian arguments that, at all levels, Serbs were more backward, barbarous, and warlike. These innate or primordial characteristics were cited as the cause of Yugoslavia's breakdown and the wars that followed.

Chapters 5 and 6 examine the Second World War, arguably the most important historical period for both sides. Serbs and Croats accused each other of being willing and zealous collaborators with the Nazi occupiers. Each accused the other of being an enthusiastic participant in the Final Solution against Yugoslavian Jews, through membership in the Serbian Četniks or the Croatian Ustaša. Each side also claimed to have suffered a 'Holocaust' at the hands of the other - the Serbs at the Ustaša-run death camp Jasenovac, the Croats, after the war, at the Austrian town of Bleiburg, when Communist Partisans (perhaps Serbian) massacred escaping collaborators. Inflating the number of victims among one's co-religionists, while reducing the numbers killed by one's own side, became a full-time occupation for many academics. 
Croatian writers inflated the Bleiburg dead, while reducing Jasenovac to the status of a medium-sized massacre. Serbs, by contrast, touted Jasenovac as the third largest death camp in Europe - often labelling it the 'Serbian Auschwitz'. The purpose of such revisions was clear. Both sides needed a powerful example of the genocidal capabilities of the other, in order to prove that more contemporary atrocities were simply a repetition of the past.

Chapter 7 will be divided into two parts, the first dealing with Serbian and Croatian views of Tito's Communist Yugoslavia, a country that suppressed nationalism, while preaching a form of consensus and harmony. Predictably, both groups would claim to have been the victims of continued persecution by the other, who they claim dominated the federation. Typically, the borders of republics were attacked, as well as the ethnic imbalances in the military, the government, and the civil service. The second and more important part of this chapter details how both Serbs and Croats constructed their pasts, and how they drew parallels between past and contemporary events. Here, Second World War comparisons were the most important, particularly for the Serbs. While the Croats too have used this period of history to their advantage, they also used earlier periods, such as the nineteenth century, and the First Yugoslavia, to argue that the Serbs had followed a continuous pattern of genocide for over a century.

Chapter 8 explores Serbian and Croatian propaganda from a fresh angle through their reactions to a third party. The war in Bosnia-Hercegovina displayed both sides at their most cynical and opportunistic. Tudjman and Milošević had already divided the republic on paper before a single shot was fired. Both sides committed war crimes, which included 'ethnic cleansing' (using terror to force people from the villages where their families had lived for centuries), the establishment of concentration camps, or 'collection centres' (where victims were beaten, tortured, raped and often killed), the destruction of physical property (including the destruction of approximately 1,400 mosques), and numerous massacres of civilian populations. Bosnian Moslems were presented as little more than an invented artificial nation, with no historic claims to territory. At best, they were members of either the Serbian or the Croatian 'authentic' nation, which meant that their lands and their language could be brought back into the national fold. At worst, the Moslems were the harbingers of a dangerous Islamic conspiracy, poised to take over the Balkans and Western Europe.

While large numbers of Serbs and Croats supported this immense propaganda campaign, there were some notable exceptions. While this work is concerned with distinctly nationalist literature, there have been conscientious writers on both sides, attempting to debunk many of the myths that emerged as a corollary to nationalism. The independent press in both countries was highly critical of their respective regimes, often infusing the debate 
with strong attacks on extreme nationalism within the government. Editors and journalists often suffered accordingly. Similarly, some writers and academics stood firm against the onslaught of nationalism. In Croatia, Dubravka Ugrešić and Slavenka Drakulić deserve special mention, as does former Croatian diplomat Vane Ivanović. During the war, numerous Croatian academics collaborated in a well-known edited work by Rada Iveković, deploring the rise of nationalism and the escalation of violence in their country. ${ }^{10}$

In Serbia, several attempts were made to combine impartial Serbian scholarship with analysis from Western academics and politicians. One such work, edited by Michael Freeman, Dušan Janjić, and Predrag Veselinović, carefully analysed the importance of liberal theories of justice and their applicability to minority rights in Yugoslavia. ${ }^{11}$ Another ambitious work, entitled Serbia Religion and War, contained critical lectures and articles published by Serbian academics who had fled Serbia in the 1980s. ${ }^{12}$ Such publications entailed certain risks, but demonstrated that not everyone had fallen into the nationalist trap, despite the strong jingoistic mentality that pervaded almost every aspect of life. There were also many politicians who chose not to participate in the violence as such, and openly condemned Tudjman and Milošević for their excesses. The new group of elected officials - the Yugoslav President Vojislav Kostunica, the Croatian Prime Minister Ivica Račan, and the Croatian President Stipe Mesić - are just a few national leaders who did not subscribe to an exclusivist or distinctly violent view of national identity. Such leaders would assume power after Tudjman's death in December 1999 and Milošević's losses in the Serbian elections during the summer of 2000.

As will be clear, many Serbian and Croatian nationalist writers have distorted and given a distinctly nationalist slant to both early and recent history. Of course, the question arises as to whether there are any 'real' or accurate representations of history. Hayden White has taken issue with the idea that there are any 'correct' historical accounts, with only 'certain rhetorical flourishes or poetic effects' to distract readers from the truth of what they are reading. ${ }^{13}$ Rather, White argues that all forms of history, be they 'annals', 'chronicles', or 'history proper', are all subject to a process of narrativising, whereby historians try to create a story from the 'real events' of history, often a story with a beginning and a conclusion, and some type of moral lesson that can be learned.

As White argues, the biases, desires, and fantasies of the historian cannot be considered separately from the events he/she is describing. Which events are chosen and how they are presented will depend on a number of personal factors. As White asks:

What is involved then, in that finding of the 'true story', that discovery of the 'real story' within or behind the events that come to us in the chaotic form of 'histori- 
cal records'? What wish is enacted, what desire is gratified by the fantasy that real events are properly represented when they can be shown to display the formal coherency of a story? In the enigma of this wish, this desire, we catch a glimpse of the cultural function of narrativising discourse in general, an intimation of the psychological impulse behind the apparently universal need not only to narrate but to give to events an aspect of narrativity. ${ }^{14}$

While there is perhaps no 'true story' or 'real story' that can emerge from any historical appraisal, both the Serbian and Croatian cases often show deliberate attempts to mislead, by either altering or removing aspects of historical events, so that these alterations cast their nation in a favourable light. In short: they rarely aimed for 'truth' in any sense of the word. For White, the historian's objectives are often an 'enigma', the product of 'psychological impulses'. In these cases, however, the objectives are clearer than in the rather opaque medieval texts White reviews. The process of 'narrativising' was certainly heightened during the wars in Croatia and Bosnia, to the extent that fantasies and desires of nationally oriented writers replaced any semblance of presenting a 'real story' à la White. Indeed, the emphasis here was on presenting history from one's own perspective rather than striving for some utopian impartial standard. While this is certainly not a process confined only to Serbs and Croats, this pernicious aspect of identity creation during the 1990s was crucial to legitimating a wide variety of nation-building activities - many of them violent. This book will compare and contrast these nationally biased views of history, highlighting the discrepancies between them.

\section{A note on methodology}

The term 'propaganda' has many negative connotations, but is not itself intrinsically negative. Political parties and corporations around the world use propaganda, or spin-doctoring, on a daily basis, to outlaw fox-hunting, promote the Euro, or sell soap. For a definition, I defer to Oliver Thomson, who, in his excellent study of mass persuasion techniques, described propaganda as 'the manipulation of public opinion' and the 'management of collective attitudes' by use of both 'political' and 'significant symbols', those symbols that represent state power and national culture. In terms of how it is spread, Thomson argued that it includes 'any means of projecting or transmitting images, ideas or information which influences behaviour in every active or passive sense. This covers every aspect of art and communication, because nearly all messages have either deliberately or accidentally some persuasive content.' 15

This is a very general definition of propaganda, which covers almost everything. Within the context of this work, Thomson's definition needs to be 
narrowed down. I will not be discussing accidental forms of persuasion, but rather deliberate attempts by Serbian and Croatian writers to manipulate public opinion in support of mobilisation for war, and the maintenance of war, both in Croatia and in Bosnia-Hercegovina. Before continuing, please allow me to add the following caveat: this book will also be examining the writings of what we might call 'armchair' nationalists - believers throughout the world who promote their own interpretations of history and current events on the internet, and in the popular press. Such people formed a crucial base of support for Croatian and Serbian nationalist regimes, climbing aboard the nationalist bandwagon even though they were often unaffiliated with either government. I am not arguing that such people had any cynical plans to destroy other nations or promote violence as such, nor that they are guilty by association of 'ethnic cleansing'. Nevertheless, in their own ways, they contributed to the escalation of events by adding more fuel to the fire; and sometimes their arguments were used in ways that they neither intended nor could have foreseen.

Throughout this book, I will be using a form of discourse analysis to explore the themes, ideas and vocabulary present in Serbian and Croatian propaganda. I have used a qualitative method of analysing primary material, isolating their most important themes and images. This is in line with Oliver Thomson's suggestion of paying attention to 'the more obvious pattern frequencies that come from a general view of contents.' ${ }^{16}$ This book, however, strives not only to present an analysis of general themes and ideas in Serbian and Croatian historical revisions but also to analyse the vocabulary and structure of their language and how it has been used.

While I have chosen a form of qualitative discourse analysis, the role of quantitative analysis should not be discounted. In a 1993 study commissioned by the Stryelsen for Psykologist Forsvar (Centre for Psychological Research) in Sweden, Marjan Malesić and a team of researchers evaluated 213 newspaper articles from Serbia and Croatia (between August 1991 and January 1992). Using a quantitative approach, they drew up tables charting the frequency of certain topics and terms used by the domestic media in each country. ${ }^{17}$ The results of this study were illuminating. In Croatia, the team noted frequent 'homeland-related metaphors', based on 'blood and soil imagery'. The media described the government's actions and those of Croatian forces as 'peace-oriented activities', with an emphasis on countering accusations that Tudjman was a 'proto-fascist'. ${ }^{18}$ The team noted similar themes in the Serbian press, with priority given to proving the self-defensive nature of their activities. Tudjman was frequently denounced as a fascist, while the persecution of the Serbs in Croatia was constantly stressed. ${ }^{19}$

The team's findings were in some ways similar to my own, that: 'communications in abnormal and extreme situations are characterised by 
generalisations combined with the use of stereotypes, labelling and valueweighted, emotionally charged attributes.' They further noted the following:

Such simplifications can be productive in the short term, especially in abnormal situations, since they ensure the required speed and simple identification. At the same time the effect of categorical patterns of thinking and of labelling is still further enhanced by the use of value-weighted and emotionally negatively charged characterisations, which possess a powerful mobilising force ... Mass media completely accomplished the role of political propaganda and war-mongering given them by the politicians. ${ }^{20}$

Even in an analysis of newspaper articles from the early stages of the conflict, it was clear that both sides were mobilising their people for an escalation of hostilities. Thus, either method of discourse analysis should furnish a clear picture of how Serbian and Croatian nationalist elites justified the rise of nationalism and escalation of hostilities to their own people, as well as to the outside world.

Hopefully, this study will be a new contribution to the expanding field of International Relations. Recently, Iver Neumann remarked in his challenging new book, The Uses of the Other, that "The discipline of international relations (IR) is witnessing a surge of interest in identity and identity formation. This development has been permitted and facilitated by the general uncertainty of a discipline which feels itself to have spent the 1980s barking up the wrong trees. A lack of faith in the old has made it easier for the new to break through. ${ }^{21}$ Fresh insight into the links between the Holocaust, nationalism theory, and contemporary warfare is long overdue. My goal throughout is to provide scope for new reflection on these and other issues.

\section{NOTES}

1 Quoted in Jonathan Glover, Humanity: A Moral History of the Twentieth Century (London: Cape, 1999) p. 130.

2 Both quoted in Richard Holbrooke, To End a War (New York: Random House, 1998) p. 24.

3 The matter is raised by Holbrooke, who blamed not only the propaganda campaign, but also Robert Kaplan's travelogue Balkan Ghosts, which gave the impression that Balkan conflicts were centuries old and hopelessly inscrutable to the outsider (ibid. pp. 22-3).

4 Geoffrey Robertson, Crimes Against Humanity: The Struggle for Global Justice (London: Penguin, 2000). Robertson provides a useful outline of human rights legislation in his 'Preface' (see pp. xiii-xiv). For an excellent description of the evolution of Human Rights norms and legislation after the Second World War, see Louis Henkin, 'Human Rights: Ideology and Aspiration, Reality and Prospect', in Samantha Power and Graham Allison (eds), Realizing Human Rights: Moving from Inspiration to Impact (New York: St Martin's Press, 2000) pp. 7-18.

5 A general overview of this type of thinking can be found in Michael Ignatieff, The Warrior's Honour (London: Chatto and Windus, 1998).

6 Elazar Barkan, The Guilt of Nations: Restitution and Negotiating Historical Injustices (New 


\section{Introduction}

York: W. W. Norton \& Company, 2000) pp. i; xi.

7 See Paul Williams, 'The International Community', in Branka Magaš and Ivo Žanič (eds), The War in Croatia and Bosnia-Herzegovina 1991-1995 (London: Frank Cass, 2001) p. 277.

8 For an excellent discussion, see Adam Roberts, 'Sins of the Secular Missionaries', The Economist (29 January 2000).

9 In 1999, however, during the NATO bombing of Yugoslavia, Croatia did charge Yugoslavia at the Hague Tribunal for genocide, arguing that the FRY had "committed aggression against Croatia in that it supported, armed, incited and directed the actions of various groups within Croatia to rebel against the democratically elected authorities'. At this stage, Yugoslavia was charged with the deaths of 22,000 people, the injuries of a further 55,000 and the displacement of 600,000. Curiously, even 'the exodus after [the Croatian-led] Operation Storm' was blamed on the Serbs. As Stjepan Mesić has argued, the motivations behind these claims were perhaps the result of 'diplomatic and political speculations', since at least one-third of the 600,000 displaced were Croatian Serbs who had fled the Croatian army in 1995: Stjepan Mesić, 'The Road to War', in Magaš and Žanić (eds), The War in Croatia and Bosnia-Herzegovina, p. 8.

10 Rada Iveković (ed.), La Croatie depuis d'effondrement de la Yougoslavie (Paris: L'Harmattan, 1994).

11 Michael Freeman, Dragomir Pantić, and Dusan Janjić (eds), Nationalism and Minorities (Belgrade: Institute of Social Sciences, 1995).

12 Dušan Janjić, Serbia Religion and War (Belgrade: IKV European Movement in Serbia, 1994).

13 Hayden White, The Content of the Form: Narrative Discourse and Historical Representation (Baltimore, MD: Johns Hopkins University Press, 1987) pp. x; 24.

14 Ibid. p. 4.

15 Oliver Thomson, Mass Persuasion in History: An Historical Analysis of the Development of Propaganda Techniques (New York: Crane, Russak \& Company, 1977) pp. 3-4.

16 Ibid. p. 9.

17 Marjan Malesić, The Role of the Mass Media in the Serbian-Croatian Conflict (Stockholm: Stryelsen for Psykologist Forsvar, 1993). Her methodology is explained on pp. 43-6.

18 Ibid. pp. 44-8.

19 Ibid. pp. 47-51.

20 Ibid.pp. 82-3.

21 Iver B. Neumann, Uses of the Other: 'The East' in European Identity Formation (Minneapolis, MN: University of Minnesota Press, 1999) p. 1. 